\section{Evaluation of Children with COVID-19 in the First Month of the Outbreak in Turkey; Initial Pediatric Data from a Tertiary Hospital}

\author{
Türkiye'de Salgının ilk Ayında COViD-19'lu \\ Çocukların Değerlendirilmesi: Üçüncü Basamak \\ Bir Hastaneden Ilk Pediatrik Veriler
}
Aybüke Akaslan Kara $\odot$ Elif Kıymet $\odot$ Elif Böncüoğlu $\odot$ Şahika Şahinkaya $\odot$ Ela Cem $\odot$ Kamile Arıkan $\odot$ Nuri Bayram $\odot$ Yaşar Tamer Alp $\odot$ Mehmet Burak Öztop $\odot$ Tanju Çelik $\odot$ ilker Devrim $\odot$

\section{ABSTRACT}

Objective: SARS-CoV-2, emerged in December 2019 in the city of Wuhan in the People's Republic of China affects children as well as all age groups. The aim of the study was to evaluate the clinical features and outcomes of pediatric cases with COVID-19 in the first month of the epidemic in Turkey.

Method: This single center cross-sectional study was conducted in University of Health Sciences Dr Behçet Uz Child Diseases and Pediatric Surgery Training and Research Hospital during the period of March 11 April 20, 2020. Demographic, epidemiological and clinical data were collected from medical records. All patients were confirmed by real time reverse transcription- polymerase chain reaction. Chidren were classified as asymptomatic, mild, moderate, severe, and critically ill patients.

Results: In this study, we reported the clinical characteristics of a case series involving 30 chilren with COVID-19 aged from 23 days to 16 years. Twenty-nine (96.7\%) patients had confirmed contact with family members for COViD-19. The majority of patients were asymptomatic (50\%) or had mild symptoms (26.7\%). Fever (46.6\%) and cough (33.3\%) were the most common symptoms.

Conclusion: Our study indicated that COVID 19 in children exhibited less severe symptoms and had better outcomes

Keywords: COVID-19, children, Turkey

öz

Amaç: SARS-CoV-2, Aralık 2019'da Çin'in Wuhan şehrinde ortaya çıkmıştır ve tüm yaş gruplarını olduğu gibi çocukları da etkilemektedir. Bu çalışmanın amacı, Türkiye'de salgının ilk ayında COVID-19 olan pediyatrik olguların klinik özelliklerini ve sonuçlarını değerlendirmektir.

Yöntem: Bu tek merkezli kesitsel çalışma, 11 Mart - 20 Nisan 2020 döneminde Sağlık Bilimleri Üniversitesi Dr. Behçet Uz Çocuk Hastalıkları ve Çocuk Cerrahisi Eğitim ve Araştırma Hastanesinde yapıldı. Hastaların tıbbi kayıtlardan demografik, epidemiyolojik ve klinik veriler toplandı. Tüm hastaların tanısı gerçek zamanIı ters transkriptaz polimeraz zincir reaksiyonu ile doğrulandı. Çocuklar kliniklerine göre asemptomatik, hafif, orta şiddetli, ağır ve kritik olarak sınıflandırıldı.

Bulgular: Bu çalışmada, KOViD-19 tanısı alan 23 gün ile 16 yaş arası 30 çocuk vaka serisinin klinik özelliklerini bildirdik. Yirmi dokuz $(\% 96,7)$ hastada teyit edilmiş KOViD 19 tanısı olan erişkin aile bireyleri ile temas mevcuttu. Pediyatrik hastaların çoğunluğu asemptomatik (\%50) idi veya hafif semptomlar $(\% 26,7)$ vardı. Ateş $(\% 46,6)$ ve öksürük $(\% 33,3)$ en sık görülen semptomlardı.

Sonuç: Çalışmamız, çocuklarda KOVID 19'un daha az şiddetli semptomlar sergilediğini ve daha iyi sonuçlara sahip olduğunu gösterdi.

Anahtar kelimeler: KOViD-19, çocuk, Türkiye
Received: 20.11 .2020

Accepted: 13.03 .2021 Published Online: 03.08.2021

Cite as: Akaslan Kara A, Kıymet E, Böncüoğlu E, Şahinkaya Ş, Cem E, Arıkan K, Bayram N, Alp YT, Öztop MB, Çelik T, Devrim I. Evaluation of children with COVID19 in the first month of the outbreak in Turkey; Initial pediatric data from a tertiary hospital. izmir Dr. Behçet Uz Çocuk Hast. Dergisi. 2021;11(2):117-22.

Aybüke Akaslan Kara Dr. Behçet Uz Çocuk Hastalıkları ve Cerrahisi Eğitim ve Araştırma Hastanesi, Çocuk Enfeksiyon Hastalıkları Bilim Dalı İzmir, Türkiye aybukeakaslan@hotmail.com ORCID: 0000-0002-9212-5155

E. Kıymet 0000-0002-7251-070X E. Böncüoğlu 0000-0002-3521-0484 Ş. Şahinkaya 0000-0002-5057-9052

E. Cem 0000-0002-5401-8367

K. Arıkan 0000-0002-3357-7952

N. Bayram 0000-0003-1802-2518

i. Devrim 0000-0002-6053-8027 Dr. Behçet Uz Çocuk Hastalıkları ve Cerrahisi Eğitim ve Araştırma Hastanesi,

Çocuk Enfeksiyon Hastalıkları Bilim Dalı izmir, Türkiye

Y.T. Alp 0000-0002-4737-3993 izmir il Sağlık Müdürlüğü, Halk Sağlığı Müdürlüğü, Başkan Yardımcısı Izmir, Türkiye

M.B. Öztop 0000-0003-2713-6381 izmir il Sağlık Müdürü, izmir, Türkiye

T. Çelik 0000-0003-3522-9406 Dr. Behçet Uz Çocuk Hastalıkları ve Cerrahisi Eğitim ve Araştırma Hastanesi, Çocuk Sağlığı ve Hastalıkları Bilim Dalı, Izmir, Türkiye 


\section{INTRODUCTION}

In December 2019, acute respiratory disease, now known as coronavirus disease 2019 (COVID-19), occurred in a cluster of patients in Wuhan City of People's Republic of China (1). As a result of rapid spread of COVID-19 worldwide, the outbreak was announced by the World Health Organization (WHO) as a pandemic on March 11, $2020^{(2)}$. In Turkey, the first case was officially confirmed on March 11, 2020 and the total number of confirmed cases increased to 90,980 and the number of deaths due to COVID19 reached 2,140 on April $20^{(3)}$.

COVID-19 is a severe respiratory disease caused by severe acute respiratory syndrome coronavirus 2 (SARSCoV-2). Different from the adults, a large proportion of infected children appears to be asymptomatic and may be a source of transmission ${ }^{(4)}$.

The symptoms of COVID-19 in children include flu-like syndrome, fever, cough, and upper respiratory signs as sore throat, stuffy nose, sneezing, and rhinorrhea ${ }^{(4)}$. Data from China suggest that children with COVID-19 had relatively milder disease and also more favorouble outcomes when compared to adults (5). In a study from China, among 44,672 symptomatic cases, none of 416 patients aged 0-9 years exited, and only one death (0.2\%) was reported among 549 patients aged 10-19 years ${ }^{(6)}$. On the other hand, severe disease may be seen especially in very young children. In fact, three deaths were reported among the pediatric cases included in the analysis from the United States between February 12-April 2, 2020 (7).

Despite the data on COVID-19 gradually iaccumulate, reports on children are still limited. In this preliminary study, epidemiological and clinical features of pediatric COVID-19 patients were evaluated in the first month of the epidemic in Turkey.

\section{MATERIAL and METHODS}

This single center cross-sectional study was conducted in University of Health Sciences Dr Behçet Uz Children's Hospital in İmir, Turkey, during the period of March 11-April 20, 2020. This hospital is a 400-bed tertiary care center serving approximately 600,000 outpatients and 24,000 in-patients per year.

All children whose diagnosis of SARS-CoV-2 infection was confirmed by quantitative real time reverse transcription-polymerase chain reaction (RT-PCR) analysis of samples taken from upper nasopharyngeal swabs were included in the study. The clinician accountable for collecting respiratory samples was educated by the infection control committee on sampling and the use of personal protective equipment. For SARS-CoV-2 PCR, first an oropharyngeal sample was taken from the patient with fever and cough/shortness of breath, then a nasopharyngeal sample was obtained using the same swab and placed in the transport medium. The samples were sent to the laboratory in accordance with the cold chain logistics rules determined by the Turkish Ministry of Health. Real Time-PCR protocol was compiled with WHO recommendation ${ }^{(8)}$. Realtime PCR was performed at local government centers for disease control and prevention. Rapid diagnosis with kit, specific SARS-CoV-2 Nucleocapsid (N) gene fragment targeting was performed by one-step reverse transcription (RT) and real-time PCR (qPCR) (RT-qPCR). (Bio-Speedy ${ }^{\circledR}$, Turkey 2019-nCoV qPCR Detection Kit) ${ }^{(9)}$.

Demographic, epidemiological and clinical data were collected from electronic medical records of the hospital and also checked from the patients written medical files.

All patients with COVID-19 infection were classified as follows: 1) Asymptomatic group included patients with positive RT-PCR test results without any clinical symptoms and signs, and normal chest imaging findings, 2) Mild disease group included patients with symptoms of acute upper respiratory tract infection but without any imaging evidence of pneumonia, 3) Moderate disease group included patients with fever and respiratory tract symptoms with imaging evidence of pneumonia, 4) Severe disease group included patients with acute hypoxia symptoms and respiratory distress, 5) Critical disease group included patients with shock, and respiratory failure ${ }^{(5)}$. 
The study protocol was approved by instutional board of $\mathrm{Dr}$ Behçet Uz Children's Diseases and Surgery Training and Research Hospital.

\section{RESULTS}

During the study period, $30(14.3 \%)$ of 209 children screened due to suspected COVID-19 disease had positive RT-PCR test results. Of these 30 children, 16 cases were female and 14 were male with a median age of 8.5 years ( 23 days-16 years). A total of $22(73.3 \%)$ patients were hospitalized including one (1/22 case, $3.3 \%)$ patient hospitalized in the neonatal intensive care unit and one $(1 / 22$ case, $3.3 \%)$ in the pediatric intensive care unit (ICU). The patient in the pediatric ICU was a 13-year-old- girl with cerebral palsy and received lopinavir/ritonavir therapy for 14 days, She received treatment in the hospital for 56 days, including 49 days in the intensive care unit. A 23-day-old asymptomatic female patient followed up in the neonatal ICU without any treatment for COVID-19 was discharged with recovery.

\section{Epidemiological characteristics}

Among 30 confirmed cases, 29 (96.7\%) had a confirmed history of contact with family members with COVID 19. Only one (3.3\%) patient had an uncertain history of exposure.

\section{Underlying diseases and comorbidities}

Of 30 cases, 28 (93.3\%) were previously healthy children without any comorbidity. One patient had bronchial hyperreactivity and the other one was a debilated patient with cerebral palsy hospitalized in the intensive care unit. A 7-year-old child with modarete symptoms and bronchial hyperactivity was treated with hydroxychloroquine and azithromycin in line with the COVID-19 management guide released by Republic of Türkey Ministry of Health ${ }^{(10)}$, and discharged with recovery.

The most common symptoms at the onset of illness were fever (14/30 cases, $46.6 \%)$, followed by cough ( $10 / 30$ cases, $33.3 \%)$, sore throat ( $2 / 30$ cases, $6.6 \%)$, and rhinorrhea (2/30 cases, $6.6 \%)$. None of the patients were suffering from diarrhea, vomiting, abdominal pain, or conjunctivitis. Fifteen (50\%) of 30 children were asymptomatic, $8(26.7 \%)$ had mild, 6 (20\%) had moderate symptoms, while one (3.3\%) patient was critically ill. Clinical and demographic characteristics of the cases are shown in Table 1.

Computed tomography (CT) scan of the lung was performed in 15 (50\%) patients with obvious infiltrations on chest radiography, and typical patterns of lung CT compatible with COVID-19 disease that were described during pandemic ${ }^{(11,12)}$ were observed in $7(23.3 \%)$ patients. The major CT abnormalities observed were mixed bilateral multifocal ground-glass opacity as detected in all 7 patients.

\section{Treatment}

Treatment was not given to the patients who were asymptomatic or with mild symptoms. Among the 30 patients, 7 (23.3\%) patients received treatment for COVID-19. Treatment with hydroxychloroquine $16.5 \mathrm{mg} / \mathrm{kg} /$ dose PO twice daily in the first day : maximum dose on the first day, $400 \mathrm{mg} /$ dose, and $3.25 \mathrm{mg} / \mathrm{kg} /$ dose twice daily for the following 4 days :maximum dose, $200 \mathrm{mg} /$ dose) with or without azithromycine $(10 \mathrm{mg} / \mathrm{kg} /$ dose PO once a day; maximum dose on the first day: $500 \mathrm{mg} /$ dose; $2-5$. days $5 \mathrm{mg} / \mathrm{kg} /$ dose once a day: maximum dose: 250 $\mathrm{mg} /$ dose) were administered in 6 (20\%) patients with moderate infection, and CT findings ${ }^{(10)}$. In additon, one patient in the intensive care unit received lopinavir/ritonavir treatment in combination with hydroxychloroquine ${ }^{(10)}$.

Since arrhythmia was described as the major adverse effect of these drugs and none of the patients had any cardiac rhythm abnormality, all patients receiving hydroxychloroquine and azithromycin treatment were monitorized for cardiac arrhythmia before and during the administration of the drugs. Short-term gastrointestinal and dermatological side effects were not observed in patients.

Currently, all of the patients have been discharged with recovery. Up to date no death has been observed among our patients. 
Table 1. Clinical and demographic characteristics of $\mathbf{3 0}$ patients enrolled in the study.

\begin{tabular}{|c|c|}
\hline Demographic characteristics and underlying medical conditions & $\mathbf{n}$ \\
\hline $\begin{array}{l}\text { Number of patients } \\
\text { Age (years), median } \\
\text { Female, } \mathrm{n}(\%)\end{array}$ & $\begin{array}{c}30 \\
8.5(23 \text { day-16 years) } \\
16(53.3)\end{array}$ \\
\hline $\begin{array}{l}\text { Exposure to the source of transmission, } \mathrm{n}(\%) \\
\text { Close-range contacts with definitely diagnosed cases } \\
\text { Data unavailable }\end{array}$ & $\begin{array}{c}29(96.7) \\
1(3.3)\end{array}$ \\
\hline $\begin{array}{l}\text { Clinical course } \\
\text { Asymptomatic } \\
\text { Mild } \\
\text { Moderate } \\
\text { Severe } \\
\text { Critical }\end{array}$ & $\begin{array}{c}15(50) \\
8(26.7) \\
6(20) \\
0 \\
1(3.3)\end{array}$ \\
\hline $\begin{array}{l}\text { Iniatial symptoms at admission } \\
\text { Fever } \\
\text { Cough } \\
\text { Sore throat } \\
\text { Rhinorrhea } \\
\text { Headache } \\
\text { Anosmia }\end{array}$ & $\begin{array}{c}14(46.6) \\
10(33.3) \\
2(6.6) \\
2(6.6) \\
1(3.3) \\
1(3.3)\end{array}$ \\
\hline
\end{tabular}

\section{DISCUSSION}

In this clinical report, the clinical characteristics and our experience concerning the management of our pediatric patients with COVID-19 disease were described. Of 30 patients, only one had a critical course, while half of the patients were asymptomatic and approximately one fourth had mild course of the disease.

COVID-19 infection is currently known as a kind of extremely severe infectious disease that was declared a pandemic. Based on available data, it is possible to emphasize that COVID-19 has been rare among children compared to adults ${ }^{(5)}$. By February 10, 2020, a total of 10,924 adult cases and 398 pediatric cases with a rate of $3.5 \%$ were confirmed in China and death was not observed among patients under 10 years of age ${ }^{(13)}$. In Italy, on March 15, 2020, a total of 22512 cases had been reported, and $1.2 \%$ of these cases were children aged $0-18$ years without any incident of death among them (14). As for April 2020, in Korea, $2.6 \%$ of the COVID-19 cases were 0-9 years and $\% 3.1$ of these cases $10-19$ years old ${ }^{(15)}$. In
Turkey, the total number of COVID-19 cases was 198.284 on 2 July 2020, and 2\% of all COVID-19 cases were in the $\leq 15$, and $13.7 \%$ of them in the $15-24$ years age group ${ }^{(16)}$.

The COVID-19 disease seems to be associated with a less severe course among children than adults (17). However, it is unclear that certain pediatric populations (children with chronic illness or on immunosuppressive therapy) will also have a positive outcome ${ }^{(18)}$. In the current study most of the children (93.3\%) were previously healthy, excluding one patient with bronchial hyperreactivity and one debilated patient with cerebral palsy. In a study of 345 pediatric cases with available information on underlying conditions, 80 (23\%) had at least one underlying condition and, chronic lung disease (including asthma), cardiovascular disease, and immunosuppressive disorders were found the most common underlying comorbidities ${ }^{(7)}$.

Children at all ages were sensitive to COVID-19, and there was no significant gender difference as was detected in this study ${ }^{(5)}$. Here, we report 30 patients with confirmed COVID-19 disease, and the 
median age of the patients was 8.5 years (range 23 days- 16 years) with a female /male ratio of 1.14 (16 girls / 14 boys). Children are often diagnosed with COVID-19 after exposure to an infected adult inside or outside the family circle, however in some cases the source of the infection could not be identified. In our study most children $(96.7 \%)$ had epidemiological contact history from their families, and transmission route of the infection was unknown in only 1 patient. Schools were closed on 16 March 2020, on the 5th day of the outbreak, and then the curfew was imposed on individuals under 20 years of age on 3 April 2020, on the 22nd day of the outbreak. In other words, we think that the majority of the sources of transmission to children in Turkey was mostly their parents or other family members. According to our experience, most important epidemiological linkage for COVID-19 positivity in children is the presence of a family member with COVID-19 infection.

The presenting clinical symptoms of pediatric COVID-19 are often atypical, mainly fever and cough. Some patients experience gastrointestinal symptoms, including abdominal discomfort, nausea, vomiting, abdominal pain and diarrhea ${ }^{(4)}$. The most frequently encountered symptoms at admission were fever and dry cough in $46.6 \%$, and $33.3 \%$ of the patients, respectively. In this study, there were no children presenting with gastrointestinal symptoms. In adults, anosmia is reported in conjunction with reported symptoms of coronavirus but it is not among the common symptoms in children. In our experience, only a 13-year-old boy who had a history of family contact had anosmia instead of cough and fever.

According to the available data, $90 \%$ of the children with COVID-19 infection were asymptomatic, or had suffered from mild or moderate disease course ${ }^{(19)}$. This study also supported this finding with only one patient requiring intubation and 6 patients having moderate disease. In a study conducted in China, among 339 pediatric cases, $5.60 \%$ of the children were asymptomatic, $93.81 \%$ had mild and $0.29 \%$ had severe disease ${ }^{(6)}$.

In the study, diagnosis of COVID19 was made with RT-PCR tests performed with throat and oral swab samples. Chest computed tomography (CT) can identify infected lesions, indicating viral pneumonia, which plays an irreplaceable role in the screening of COVID-19 disease in adults ${ }^{(11)}$. However, limited data are available in children regarding the typical chest $\mathrm{CT}$ imaging findings and when to make re-imaging. CT imaging was performed in 15 (50\%) patients and CT findings were compatible with COVID 19 disease in 7 (23.3) patients. In this study, mixed bilateral multifocal ground-glass opacity were the major CT abnormalities observed

Currently regarding treatments for COVID-19 infection in children, there is no data with sufficient level of scientific evidence. Most literature relates to adult-onset COVID-19 disease, but these findings are not always applicable to children. Also, in children, possible side effects should also be considered when making a treatment decision. At the moment, treatment recommendations to date are based on only observations. In our clinic, treatment was not started for the asymptomatic child. Hydroxychloroquine with/without azithromycin treatment was received by $6(20 \%)$ children with moderate infection and CT findings compatible with COVID 19, while one patient treated in the intensive care unit received lopinavir/ritonavir treatment. However with increasing knowledge and experience derived from studies performed in adults, we preferred to treat children with moderate infections and relevant $\mathrm{CT}$ findings with hydroxychloroquine alone. None of the patients treated with hydroxychloroquine with/without azithromycin had abnormalities in their electrocardiograms (ECG).

This study has several limitations. Firstly, it has a small sample size. A larger, cohort study population will be needed to characterize more fully the clinical characteristics of children with COVID-19 infection. Secondly, the diagnosis of the cases was established based on only the results of the RT-PCR tests. Indeed, CT scans in children are not diagnostic for COVID-19 disease, unlike adults. Thus, many cases with asymptomatic or mild disease might remain undiagnosed in this population. 


\section{CONCLUSION}

Our preliminary clinical findings concluded that pediatric patients with COVID 19 disease mostly have mild respiratory infections than adult cases and the transmission in children might primarily occur through contact with adult patients, mainly through household exposure. Though, current information about COVID-19 disease in children is still limited, the disease in children seems to have a mild course. However the activity and disease spectrum of the COVID-19 disease should be monitored in children for possible development of COVID-19 spectrum.

Ethics Committee Approval: The study protocol was approved by instutional board of Dr Behçet Uz Children's Diseases and Surgery Training and Research Hospital and Türkey Ministry of Health, written parental informed consent was obtained for all participants.

Conflict of Interest: The authors declare that they have no competing interests.

Funding: The author(s) received no financial support for the research, authorship, and/or publication of this article.

Informed Consent: Children over the age of nine have been given written consent from both their parents and themselves.

\section{REFERENCES}

1. Li Q, Guan X, Wu P, Wang X, Zhou L et al. Early transmission dynamics in Wuhan, China, of novel coronavirus-infected pneumonia. New England Journal of Medicine 2020;382:13): 1199-207. https://doi.org/10.1056/NEJMoa2001316

2. "WHO Director-General's opening remarks at the media briefing on COVID-19-11 March 2020". World Health Organization. 11 March 2020. Retrieved 11 March 2020. https://www.who.int/dg/speeches/detail/who-directorgeneral-s-opening-remarks-at-the-media-briefing-on-covid19---11-march-2020 (date last accessed 25.04.2020)

3. T. C. Ministry of Health New Type Corovirus table, Available from: https://COVID19.saglik.gov.tr/. Date last accessed; 20.04.2020).

4. Cai J, Xu J, Lin D, et al. A Case Series Of Children with 2019 novel coronavirus infection: clinical and epidemiological features. Clin Infect Dis 2020. ciaa198.

https://doi.org/10.1093/cid/ciaa198

5. Dong Y, Mo X, Hu Y, et al. Epidemiological characteristics of 2143 pediatric patients with 2019 coronavirus disease in China. Pediatrics 2020. Epub March 16, 2020. https://doi.org/10.1542/peds.2020-0702

6. Liu Z, Bing X, Zhi XZ. The epidemiological characteristics of an outbreak of2019 novel coronavirus diseases (COVID-19) in China . Zhonghua Liu XingBing Xue Za Zhi 2020;41:145-51.

7. CDC COVID-19 Response Team. Coronavirus Disease 2019 in Children - United States, February 12-April 2, 2020. MMWR Morb Mortal Wkly Rep. 2020;69(14):422-6. https://doi.org/10.15585/mmwr.mm6914e4

8. World Health Organization. Laboratory testing for coronavirus disease (COVID-19) in suspected human cases. https://www. who.int/publications-detail/laboratory-testing-for-2019novel-coronavirus-in-suspected-human-cases-20200117. (Last updated 25 April 2020)

9. Bio speedy- SARS-CoV-2 (2019-nCoV) qPCR Detection Kit, Available from: https://www.bioeksen.com.tr/sars-cov2-nrtqpcr-kit (Last updated 25 April 2021)

10. Republic of Türkey Ministry of Health, COVID-19 (SARS-CoV-2 Infection) Child Patient Management AndTreatment Guide. April 14, 2020 Available at: https://ohsad.org/wp-content/ uploads/2020/04/COVID-19_Rehberi-2.pdf

11. Li B, Shen J, Li L, Yu C. Radiographic and Clinical Features of Children with 2019Coronavirus (COVID19) Pneumonia. Indian Pediatr. 2020 Apr 7. pii: S097475591600156.

12. Chung M, Bernheim A, Mei X, et al. CT Imaging Features of 2019 Novel Coronavirus (2019-nCoV). Radiology. 2020;295(1):202-7. https://doi.org/10.1148/radiol.2020200230

13. Cao Q, Chen YC, Chen CL, Chiu CH. SARS-CoV-2 infection in children:transmission dynamics and clinical characteristics. J Formos Med Assoc 2020;119:670-3. https://doi.org/10.1016/j.jfma.2020.02.009

14. Edward Livingston, MD; Karen Bucher, MA. Coronavirus Disease 2019 (COVID-19) in Italy. JAMA. 2020;323(14):1335. https://doi.org/10.1001/jama.2020.4344.

15. Korea Centers for Disease Control and Prevention. The updates ofCOVID-19 in Republic of Korea, as of 21 April, 2020. Cheongju (Korea): Korea Centers for Disease Control and Prevention, 2020. https://www.cdc.go.kr/board/board. es? $\mathrm{mid}=\mathrm{a} 30402000000 \& \mathrm{bid}=0030$, (Last updated 25 April 2020)

16. COVID-19 Stiation Report Turkey 30 June 2020. Available at: https://dosyamerkez.saglik.gov.tr/Eklenti/37778,covid-19durum-raporupdf.pdf?0 Accessed July 2, 2020.

17. Hong $\mathrm{H}$, Wang $\mathrm{Y}$, Chung HT Clinical characteristics of novel coronavirus disease 2019 (COVID-19) in newborns, infants and children. Pediatr Neonatol. 2020 Apr;61(2):131-2. https://doi.org/10.1016/j.pedneo.2020.03.001

18. Morand A, Fabre A, Minodier P, Boutin A, Vanel N, Bosdure $\mathrm{E}$, et al. COVID-19 virus and children : What do we know ? Arch Pédiatrie. 2020;27(3):117-8. https://doi.org/10.1016/j.arcped.2020.03.001

19. Dong Y, Mo X, Hu Y, Qi X, Jiang F, et al. Epidemiology of COVID-19 among children In China. Pediatrics 2020. https://doi.org/10.1542/peds.2020-0702 